It will depend on the state of affairs in that region whether the expedition afterwards crosses the Hindoo Koosh to Cabul and Candahar, and proceeds to India and China, or whether it takes the road to Pekin through Kashgaria and Thibet. Persia and Asia Minor will be touched on the way home, and Prof, d'Ujfalvy hopes to reach Paris by the beginning of 1882 . D'Ujfalvy has received a subsidy of 80,000 francs from the French Government, and is accompanied by two salaried officials connected with the Ministry of Public Instruction, Gabriel Bonvalo, a naturalist, and Guillaume Kapius, a doctor of natural science.

THE current number of the Geographical Society's Proceedings opens with Sir R. Temple's lecture on the highway from the Indus to Candahar (illustrated by woodcuts from his own sketches), which is most appropriately followed by Capt. Beavan's "Notes on the Country between Candahar and Girishk." The map, which will embody new material, is promised with next number. The other paper is an account by $\mathrm{Mr}$. Coppinger, R.N,, of a visit to Skyring Water, Straits of Magellan. In the geographical notes much prominence is naturally given to Mr. Thomson's letters describing the concluding part of his very successful journey in East Africa, the only disaster of which has been the sad death of Mr. Keith Johnston at the very outset. In the letters now before us Mr. Thomson tells us how he vainly -owing to the opposition of his own men-endeavoured to trace the course of the Lukuga Creek from Lake Tanganyika to the Congo, failing in which he returned to his camp at the south of the lake, and then, having examined the previously unseen Lake Hikwa (or Likwa), made the best of his way back to Zanzibar through Unyanyembe. Among the other notes we find one on the French expedition from the Senegal to the Niger, under Capt. Galliéni, followed by others on routes between Kurram and Ghazni, Russian Manchuria, Saghalin Island, the Indo-Chinese peninsula, and the affluents of the Rio Purûs. Sir J. H. Lefroy's address to the Geographical Section of the British Association is also given, together with a few notes on new books and maps, the whole forming an exceedingly good number for the time of the year.

AfTer spending two years in South Africa, Lieut. Een, a Swedish traveller, has lately returned to Europe, bringing with him valuable collections which he has formed in Damara-land, in the departments of natural history and ethnography.

CAPT. CASA'T, an Italian traveller, is going to the Bahr-elGhazal, whence he will endeavour to reach Lake Chad through the Niam-Niam country, with the view of thoroughly investigating the interesting problem of the relations between the Rivers Welle and Shari.

M. I.OMBARD has gone to Abyssinia on a mission from the French Government, to study the topography of the country, as well as its civil and military organisation.

THE last issue of Le Globe contains a paper on "La Topographie comme Base de l'Enseignement géographique," and another by M. Th. Vernet, on South Africa.

THE current number of Les Missions Catholiques contains three papers of interest, viz., the conclusion of the narrative of a journey in West Africa, part of the particulars respecting the march of the Algerian Missionary Society's last expeditions to Lake Tanganyika and the Victoria Nyanza, and the first instal ment of a paper communicated by the Very Rev. Father Dominique of Aden, on Somali-land, a region which is gradually attracting a good deal of attention at the hands of travellers as well as of missionaries.

THE most noteworthy contributions to the new number of Les Annales de l'Extrime Orient are a notice of M. Aymonnier's Khmer-French Dictionary, and a vocabulary collected by the wellknown Thibetan traveller, Abbé Desgodins, of words in use among several tribes on the Lan-tsang-kiang, or Upper Me-kong, the Lou-tsé-kiang, or Upper Salween, and the Upper Irrawaddy.

A TrLegram from San Francisco, dated the ist inst., states that a despatch has been received at that port from Victoria, a district at the northern extremity of $\Lambda$ merica, to the effect that the barque Malay has arrived. there from Ounalaska, bringing no tidings of the Fannette, the vessel despatched some months ago by the United States Government upon a voyage of Polar discovery. The Malay reported that at Ounalask a the feanneltc was given up for lost, on account of the severity of last winter. A despatch from Washington, in reference to the above rumour, ridicules the idea that the foannelte has met with a mishap, inasmuch as she was made as strong as human ingenvity could contrive, and specially equipped and provided for the service on which she was sent. Officers, says the Herald, who have had experience of the Arctic seas, say they know of no reason why Lieut. De Long should not be as successful as Nordenskjöld was in his Northern voyage.

Tire series of letters from the enterprising correspundent of the Daily News in Central Asia are well worthy of attention; they contain many valuable observations both on the country and the people. The Burmese correspondent of the same paper, in a long letter in last Friday's issue, describes a journey into the interior, giving much fresh information on a little known region.

\section{THE FRENCH DEEP-SEA EXPLORATION IN THE BAY OF BISCAY 1}

I FEEL that I am indebted for the opportunity of giving an account of the French Expedition which forms the subject of this paper to my esteemed friend and colleague the Marquis de Folin of Bayonne. He was until lately the Commandant of that port, and is a most zealous and excellent naturalist. I may indeed say that the Expedition originated with him. For more than ten years he had at his own expense assiduously and carefully explored the sea-bed Iying off Cap Breton, in the Department of the Landes, as well as could be done in a fishing-boat; and the result of his researches among the marine Invertebrata has been described, with illustrations by his pencil, in a nseful work called, "Les Fonds de la Mer," published at Bayonne,under his direction, M. de Folin has from time to time sent me the mollusca procured in his dredgings for my opinion ; and our correspondence, with a visit which 1 paid him in December, 1878 , led to his making an application to the French Government for the grant of a vessel to explore the depths which were known to exist at a comparatively short distance from the northern coasts of Spain in the Bay of Biscay. This evidently could not be done in a fishing-boat; and naturalists have much less money than science. It was in fact a project for a nation, and not for an individual. The application was, I believe, referred to the Dean of the Academy of Sciences, M. Milne-Edwards, whose reputation as an eminent zoologist has been universally recognised for more than half a century. His report was favourable; and a Government vessel was ordered to be placed at the disposal of a Commission, of which M. Milne-Edwards was appointed president. The other members of the Commission were the Marquis de Folin, Prof, Alphonse Milne-Edwards, Prof. Vaillant, Prof. Marion of Marseilles, Dr. Paul Fischer, and M. Perier of Bordeaux. The selection of these savants augured well for the success of the Expedition, and it has bcen fully justified. At the suggestion of M. de Folin, the Minister of Public Instruction graciously invited me and the Rev. A. M. Norman (a well.known zoologist) to take part in the expedition. Mr. Norman had been my valued companion for many years past in similar but less important excursions to Shetland and Norway. It was to me a great pleasure to be again associated with him. I regarded the invitation as far more than a compliment : it was a great honour.

I may here mention that immediately before the commencement of the Expedition M. de Folin, Mr. Norman, and I had some preparatory boat-dredging in the Fosse de Cap Breton. This was done at the expense of the French Government. When has our own Government shown such generosity in the cause of science to French naturalists?

The vessel assigned for the purposes of the Expedition was the T'ravailleur, a paddle-wheel steamer of over 900 tons, of I 50 horse-power, and carrying four guns. She is an "aviso," or despatch.boat, and is stationed at Rochefort for occasional service. She was supplied with a capital donkey-engine and immense stores of cordage, sounding-wire, and other apparratus, She had a very happy nanc, being an indefatigable worker. Capt. I. M. F. Richard was the commander, or "Lieutenunt de Vaisseau;" and the other officers were Lieutenants Mahieux, Jecquct, Villegente, and Bourget, Aide-Comn missaire Gol1ssclin, and Doctor Duplouy. Let me now express my sincere thanks to the officers for their great kindness and urbanity. They took a great interest in the work, and materially promoted the welfare of the Expedition. The crew consisted of 128 men; the usual number was between eighty and ninety, but ${ }^{r}$ Paper read at the British Association by J. Gwyn Jeffreys, LL.D., F.R.S. 
extra hands were taken in consequence of the heavy work entailed by sounding during the night. All these men seemed to be well conducted, as well as good sailors; and although they had only two meals a day, their physique was quite equal to that of our best British seamen. Mr. Norman and I took with us as dredger a steady and intelligent man, John Wilson; and Prof. Marion had his dredger, named Armand. These men were of great use in sifting the material brought up by the dredges. For the Captain, I can only echo the opinion expressed by Prof. A. MilneEdwards in his Preliminary Report, that his arrangements were first rate, and his skill admirable, especially considering that the kind of work was new to him, and that he had not previously made or even seen any deep-sea dredging.

The members of the Commission assembled at Bayonne, and the Travailleur arrived there on July 16 th. The next morning she went to sea, with all the party on board except the President, who was obliged to return to Paris, and might also have justly claimed exemption from active service, being in his eightieth year. Until August Ist (with the exception of Sundays, the I $8 \mathrm{th}_{2}$ and 25 th, which we spent at San Sebastian and Santander) we were hard at work sounding, dredging, and trawling. The weather was very fine; and the dreaded Bay of Biscay lost its stormy character on this occasion.

The principal object of the Expedition was to ascertain the nature of the fauna which inhabits at considerable depths this part of the Bay of Biscay; and this object was thoroughly and successfully accomplished. Twenty-three dredgings were made for that purpose at depths ranging from 337 to 2600 mètres, each mètre being about thirty-nine inches, or rather more than half a fathom. The dredgings between 600 and 1,000 fathoms were the most important. Every department of the Invertebrata was well represented; and novelties were discovered in Mollusca, Crustacea, Echinoderms, Annelids, Actinozoa, and Sponges.

As regards myself, this Expedition had a peculiar charm. Having had the scientific charge of similar expeditions for the Royal Society in H.M.S. Porcupine in 1869 and 1870 , and in H.M.S. Valorous in 1875 , and having examined the collections made during the voyages in H.M.SS. Shearwater and Challenger, as well as those made in nearly all the Swedish, Norwegian, Dutch, and American deep-sea and exploring expeditions in the North Atlantic, I was naturally glad to participate in the French Expedition, and particularly as it embraced that part of the sea which was at no great distance from the scene of my former labours in the cruise of the Porcupine along the western coasts of Spain and Portugal, and which cruise was so unusually productive. Impelled by this recollection, I made last year a verbal and informal application to the late First Lord of our Admiralty for the use of one of Her Majesty's ships to explore the Bay of Biscay this summer. The answer I received was very favourable; but the pecuniary resources of our Government were then at a very low ebb, and I was en. couraged to renew the application when commerce revived and times became more prosperous. I hope our new Government will avail itself of the now improved finances, and not neglect this genuine and beneficial method of instructing the nation and maintaining its credit for maritime discovery.

The fauna observed during the Travailleur's cruise closely resembled that which I ascertained during the Porcupine cruise in 1870 to exist at corresponding depths. This will be shown, so far as the Mollusca are concerned, in the list of species appended to the present paper; and I have no doubt that the other branches, when they have been worked out by the experienced naturalists to whom they have been assigned, will confirm my opinion.

In a physical and geological point of view this French Expedition has borne good fruit. No less than ro3 soundings were made. They have proved the existence, within a few miles of the coast, of a submarine valley opening from the Fosse de Cap Breton and extending to a point opposite Cap Pẽnas. The large diagram and chart which I now exhibit will give a better explanation than I can do by any words. The diagram was prepared for me when I presented to the Royal Society my Reports of the Porcupine Expeditions of 1869 and 1870 ; and the chart has been filled up and given to me by my kind friend the Hydrographer.

The striking inequalities of depth within a narrow area which thus appear were noticed in a Bayonne newspaper of August $4^{\text {th }}$ as "des grands fonds sous-marins, qui continuent sous les eaux de l'Atlantique les vallées pyrénéennes." As a general rule, it may be said that where mountains or high land approach the sea the depth of water is greater off that coast than where the land lies low. But this must depend in a great measure on the geological nature of the land adjacent to the sea. If the formation be granitic or gneissic, the wear and tear or denudation must be slower than if the formation be sandstone, Cretaceotus, or Tertiary; and the action of rivers and streams on the surface of the Iand must be proportionally increased or decreased, and must cause the sea-bed to be more or less filled up in the course of time. Everywhere during the dredgings of the Travailleur in deep water the sea-bed was found to be covered by a thick layer of mud, of a different colour from that of the Atlantic ooze; and this mud has probably accumulated from untold ages by the incessant efflux of the Gironde, the Adour, and numerous other rivers and streams into the Bay of Biscay. As may be supposed, the fauna which inhabits such mud is very scanty; and it required a considerable amount of patience and perseverance to extract a few organisms from the unpromising material. No wonder that Dr. Carpenter was discouraged, as a zoologist, by what he termed "the singular barrenness of this deposit in regard to animal life," when he described the Mediterranean cruise of the Porcupine in 1870.

Within a few days after the return of the Expedition Prof. A. Milne-Edwards presented to the Academy of Sciences at Paris a Preliminary Report of the zoological results of the Expeditton, which was published in the Fournal Officiel de la Reppublique Française. As most of the departments of the marine Invertebrata have been so fully and carefully treated by him in this Report, I will content myself with a few supplementary remarks as to the Mollusca, which especially engaged my attention during the cruise. At the request of Dr. Fischer, who will undertake this department, and with the sanction of the President, I was entrusted with all the more critical specimens of Mollusca : and these specimens I have now cleaned, assorted, and corrtpared with my own collection from the Porcupine Expedition of 1870 , on the western coasts of Spain and Portugal. I subjoin a complete list of the Travailleur Mollusca, distinguishing in separate columns those species which are Porcupine, those which were previously known to me from Norway or the Mediterranean only, and those which I consider new to science. The total number of the species in this list is 152 , out of which 138 are Porcupine, three only appear to be peculiarly northern, one peculiarly southern or Mediterranean, and eleven new to science.

The results, especially in the last-mentioned category, are most noteworthy. They serve to show how little we lknow of the deep-water Mollusca, when we reflect that the area of the seabed lately explored in a short period of time, and in a necessarily cursory manner, is but a very small corner of the Atlantic, and that it would take many years to complete the exploration so auspiciously commenced. The area traversed by the dredge during this cruise represents probably much less than a ten-thousandth part of the sea-bed lying between Cape Breton and Cape Pènas; and our means of exploration by the dredge are by no means satisfactory, particularly on muddy ground, of which the deep-water zone is mainly composed. Instead of our being able to scrape a few inches of the surface of the sea-bed at considerable depths, so as to collect in the dredge all the animals which inhabit the superficial layer, we find too often, to our disappointment, that the dredge, when it reaches the bottom, sinks into the mud from its own weight and from the momentum given to it by the motion of the ship, and that it then acts as a subsoil plough, and not as a scraper. I must ask one of my engineering friends to devise some instrument more efficient than the modern dredge.

Although it cannot be positively stated that the abyssal zone, or even the benthal zone, is inhabited only by certain species of Mollusca, some species observed by me during the preparatory excursion to Cap Breton and the Travailleur cruise bear out the statement to some extent. For instance, Nucula nitida, Dischides bifissus, Rissoa abyssicola (a now inappropriate specific name), and Defrancia decussata occurred only in the shallow water excursion; while Nucula corbulö̈des, Siphodentalium olivi, Rissoa deliciosa, and Defrancia hispidulla, occurred only in the deep-water cruize.

Several deep-water species of Mollusca occurred in this Expedition, which had been until lately supposed to be extinct; they are fossils of the Upper Tertiaries of Europe. For the Geological definition of this term see "British Conchology," vol. i. pp. 315, 316.

A curious provision of nature-if we may in these philosophical days use such a phrase-was observable in the case of 
a deep-water mussel of considerable size, which I propose to name Mytilus luteus. It inhabits the layer of mud which I have above described, and moors or fixes itself by means of a large and densely-matted byssus which is spun by the foot This byssus is capable of being spread over a considerable extent of surface; and it not only prevents the mollusk sinking into the soft mud and being smothered or buried alive, but enables it to feed comfortably on the innumerable animalcula which swarm on the surface of the sea-bed. It is of the same use to the mollusk as the snow-shoe is to the Arctic traveller. This species of Mytilus I at first took to be the Modiole incurvata of Philippi-M. martorelli of Hidalgo, which lives on the south coast of Spain in rather shallow water; but on comparison I am satisfied that they differ essentially in shape, sculpture, colour, and epidermis.

I cannot conclude this account without acknowledging my most grateful thanks to the French Government for their extremely generous conduct in my case and for the excellent hospitality which I enjoyed on boaid the Travailleur, as well as to the President and Members of the Scientific Commission for their obliging and friendly companionship.

The zoological results of this French Expedition are fully equal to those made by Capt. Baudon in 180r, M. d'Urville in 1829, the Recherche in 1835, the Astrolabe in 1841, and other French expeditions ; and I sincerely hope that a further expedition of the present kind may take place next year in the Mediterranean, where our good and gallant neighbours have such an important stake.

The list of Mollusca referred to in this paper includes the following new species named or recognised by the author:Pecten obliquatus, Lima Feffreysi (Fischer), Mytilus luteus, Modiolaria cuneata, Axinus tortuosus, Mytilimeria (?) Fischeri, Thracia tenera, Cadulus semistriatus, Rimula asturiana, Odostomia lineata, and Bullina elongata. The species which he considers peculiarly northern are Chiton alvoolus, G. O. Sars, Frusus turgidulus, Jeffreys, and Pleurotoma nivalis, Lovén; and the species which he considers peculiarly southern or Mediterranean is Odostomia fasciatus, Forbes.

THE SHOWER OF AUGUST PERSEIDS, 1880

THE August meteors were observed under peculiarly favourable circumstances this year. Not only was the moon entirely absent during the display, but the weather, which so frequently interrupts such observations, remained fine night after night, thus allowing an unbroken series of watches to be main tained from the 6th to the $13^{\text {th, }}$ and enabling the rise and fall of the display to be distinctly traced from a comparison of the results obtained each night. On the roth, however, when the maximum was expected, the state of the sky scarcely admitted of successful observation, and the number of shooting-stars recorded that night was below the experiences of past years, but it must be remembered that, this being leap year, the chief intensity of the shower was due earlier than usual, so that it may have occurred before the evening of the roth, when observers generally were watching for its reappearance.

At Bristol the following summary was derived from observations by the writer :-

\begin{tabular}{|c|c|c|c|c|c|c|c|}
\hline \multirow{2}{*}{$\begin{array}{l}\text { Date, } \\
\text { 1880. }\end{array}$} & \multirow{2}{*}{ 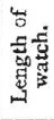 } & \multirow{2}{*}{$\begin{array}{l}\text { Time of } \\
\text { watch. }\end{array}$} & \multirow{2}{*}{$\begin{array}{l}\text { No. of } \\
\text { meteors } \\
\text { seen. }\end{array}$} & \multirow{2}{*}{ 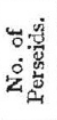 } & \multicolumn{2}{|c|}{$\begin{array}{l}\text { Horary Nos. for } \\
\text { one observer. }\end{array}$} & \multirow{2}{*}{$\begin{array}{l}\text { Chief } \\
\text { radiant } \\
\text { point. }\end{array}$} \\
\hline & & & & & $\begin{array}{c}\text { All } \\
\text { meteors. }\end{array}$ & Perseids. & \\
\hline $\begin{array}{r}\text { August } 6 \\
7-8 \\
9 \\
10 \\
11 \\
12 \\
13\end{array}$ & 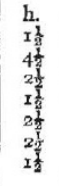 & 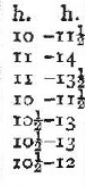 & $\begin{array}{r}19 \\
112 \\
111 \\
50 \\
64 \\
45 \\
18\end{array}$ & $\begin{array}{r}5 \\
54 \\
71 \\
4 \mathrm{~T} \\
43 \\
19 \\
7\end{array}$ & $\begin{array}{l}13 \\
25 \\
44 \\
34 \\
26 \\
18 \\
22\end{array}$ & $\left.\begin{array}{r}3 \\
\begin{array}{r}3 \\
2\end{array} \\
28 \\
28 \\
17 \\
8 \\
5\end{array}\right\}$ & $\begin{array}{l}3^{8}+5^{\circ} 6 \\
4 \mathrm{x}+55 \\
44+55 \\
45+57 \\
48+57 \\
49 \frac{1}{2}+57 \frac{1}{3}\end{array}$ \\
\hline ig. $6-x_{3}$ & $16 \frac{1}{2}$ & $10-14$ & $4^{19}$ & 240 & $24 \cdot 6$ & $\mathrm{I}_{4} \cdot 4$ & $44+56$ \\
\hline
\end{tabular}

The observed maximum occurred on the 9 th, when, during a watch of $2 \frac{1}{2}$ hours, meteors were falling at the rate of 44 per hour (for one observer), and the proportion of Perseids was nearly two-thirds of the aggregate number visible. On the roth the horary number of 34 was determined under less favourable eonditions, A fog partially overspread the sky, rendering the stars dim, so that many small meteors passed unrecorded, and at II $\frac{1}{2} \mathrm{~h}$. it was found impracticable to continue observations. The horary number of Perseids found on the Ioth coincides with that of the preceding night, and it is obvious that, allowing for the clearer atmosphere of the 9 th, the maximum of the display really occurred as usual on the Ioth. It is fair to assume from the numbers actually counted in the fog-shrouded sky of the Ioth that later in the night, as the radiant attained greater elevation, the meteors from Perseus were as numerous as during the few preceding apparitions of the shower. The brightest meteor observed at Bristol appeared at $13 \mathrm{~h} .37 \mathrm{~m}$., on August 8. The sky had become overcast except near the western horizon, where a few stars could still be distinguished. A vivid flash startled the observer, who, on looking towards the direction indicated, at once saw a brilliant meteor streak attached to the star $\gamma$ Ophiuchi, and its position was such as to leave no doubt that it had been left by a magnificent Perseid. Other large meteors were registered as follows :-

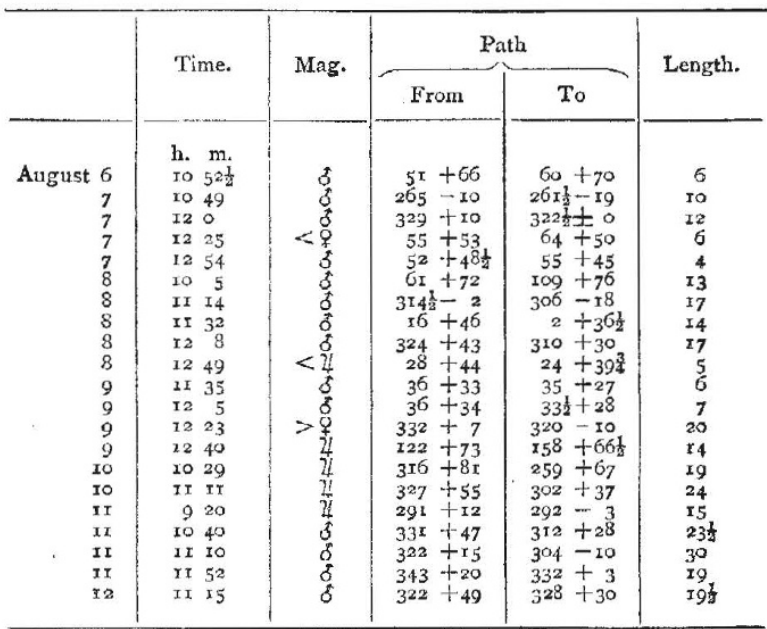

These meteors all belonged to the shower of Perseids. Motions very swift. They all left bright streaks.

The radiant point showed a displacement on nearly every successive night of observation. It was noted at $38^{\circ}+56^{\circ}$ on the 6 th, yet on the $13^{\text {th }}$ a few meteors indicated it very exactly at $49 \frac{10}{2}+57 \frac{1}{2}^{\circ}$. This corroborates observations made by the writer in 1877 , and reported in NATURE, vol. xvi. p. 362. A large number of Perseids were seen that year, and from an exact record of their flights the radiant point was seen to advance in R.A. as follows :-

$$
\begin{aligned}
& { }_{18} 87 \text {, August } 3-7=a 0^{\circ}+{ }^{\circ} \\
& \begin{array}{l}
\text { Io }=43^{\circ}+58^{\circ} \\
12=50+56^{\circ}
\end{array} \\
& 16=60^{\circ}+59^{\circ}
\end{aligned}
$$

This is further borne out by Mr. Henry Corder's extensive observations at Writtle, near Chelmsford, during the recent display, which may be tabulated as under:-

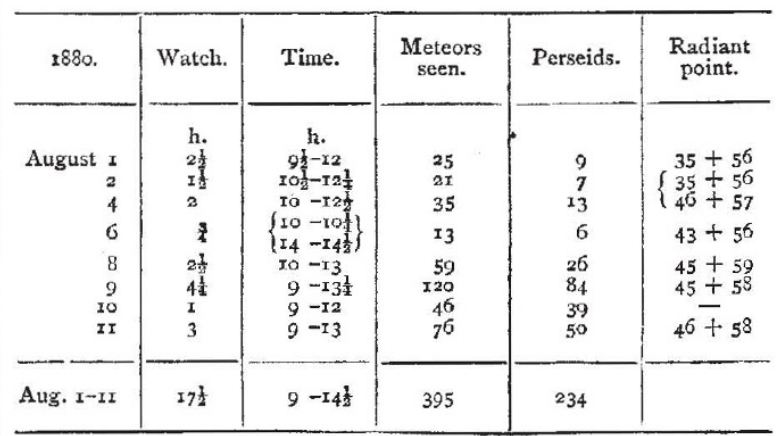

$\mathrm{Mr}$. Corder places the average position of the radiant of the true Perseids at $45^{\circ}+58^{\circ}$. On the first few nights of August he found it well defined at $35^{\circ}+56^{\circ}$, though on the IIth it had apparently shifted to $46^{\circ}+58^{\circ}$. And it is to be remarked that 